\title{
Freeze stress of deciduous trees induces attacks by opportunistic ambrosia beetles
}

\author{
Christopher M. Ranger ${ }^{* \dagger \dagger}$ (1) Peter B. Schultz ${ }^{\ddagger}$, Steven D. Frank ${ }^{\S}$ and Michael E. Reding ${ }^{* \dagger}$ \\ *USDA-Agricultural Research Service, Horticultural Insects Research Laboratory, 1680 Madison Ave., Wooster, OH 44691, U.S.A., † Department \\ of Entomology, The Ohio State University, Ohio Agricultural Research and Development Center, 1680 Madison Ave., Wooster, OH 44691, U.S.A., \\ ${ }^{\sharp}$ Hampton Roads Agricultural Research and Extension Center, Virginia Polytechnic Institute and State University, 1444 Diamond Springs Road, \\ Virginia Beach, VA 23455, U.S.A. and ${ }^{\S}$ Department of Entomology, North Carolina State University, Campus Box 7613, Raleigh, NC 27695, U.S.A.
}

\begin{abstract}
A broad host range and the utilization of living but weakened trees contribute, in part, to the invasion success of ambrosia beetles (Curculionidae: Scolytinae). The present study assessed the capability of freeze stress to induce attacks by ambrosia beetles.

2 Freeze stress predisposed Cercis canadensis L., Cornus florida L., Malus pumila Mill. and Styrax japonicus Sieb. to attack under field conditions, although no attacks occurred on untreated trees. More attacks occurred on freeze-stressed versus flood-stressed M. pumila in Virginia but not for S. japonicus in Ohio. Attacks on flooded trees were skewed towards the base of the trunk, whereas attacks on freeze-stressed trees mainly occurred around the upper regions of the trunk and into the branches. The predominant species recovered were Anisandrus maiche Stark and Xylosandrus germanus (Blandford) in Ohio, and Xylosandrus crassiusculus (Motschulsky) in Virginia.

3 Ethanol emissions from trunks of S. japonicus were detected by solid phase microextraction-gas chromatography-mass spectrometry at 1 day after imposing freeze stress, peaking 4 days after injury.

4 Trees with an intolerance of freeze stress are predicted to be vulnerable to attack, especially when subjected to mild winter temperatures followed by late-spring freezes. Freeze stress could thereby facilitate the destructiveness of exotic ambrosia beetles.
\end{abstract}

Keywords Anisandrus maiche, ethanol, freeze stress, Xylosandrus germanus, Xylosandrus crassiusculus.

\section{Introduction}

Ambrosia beetles (Curculionidae: Scolytinae) in the tribe Xyleborini are among the most successful and destructive wood-boring insects worldwide (Hulcr \& Stelinski, 2017). Thirty non-native species of Xyleborini are currently established in North America (Gomez et al., 2018) and the Xyleborini also represent half of the exotic Scolytinae introduced into Europe (Kirkendall \& Faccoli, 2010). After dispersing from their natal galleries, adult females tunnel into host trees tissues, where they establish and cultivate gardens of their nutritional fungal symbiont (Hulcr \& Stelinski, 2017). Adult females carry spores of their fungal symbiont within specialized structures called mycangia, which are then used to inoculate the tunnel walls

Correspondence: Christopher Ranger. Tel.: +330263 3897; Fax: +330 263 3696; e-mail: christopher.ranger@ars.usda.gov of host tissues. The fungal symbionts are usually Ambrosiella and Raffaelea spp., although examples also exist of mutualism with Fusarium spp. (Kasson et al., 2013; Kostovcik et al., 2015; O'Donnell et al., 2015). Oviposition occurs after the fungal gardens are flourishing, with the larvae and adults consuming the fungal symbiont to properly develop and reproduce (French \& Roeper, 1972; Biedermann \& Taborsky, 2011). Xyleborini offspring are produced via haplodiploid reproduction and sibling mating subsequently occurs between the haploid males and diploid females. Their cryptic wood-boring behaviour, fungus farming lifestyle, haplodiploid reproduction and sibling mating likely contribute to the invasion success of ambrosia beetles (Smith \& Hulcr, 2015; Gomez et al., 2018). A broad host tree range and association with weakened trees also likely promotes the establishment and proliferation of ambrosia beetles introduced into new habitats, with this relationship probably being 
facilitated by extreme climatic events producing an availability of weakened host resources (Ranger et al., 2013, 2015a, b).

Ambrosia beetles are often ranked among the most destructive insect pests of trees growing in ornamental nurseries because of their wood-boring behaviour and association with branch dieback and tree death (Oliver \& Mannion, 2001; Fulcher et al., 2012; Ranger et al., 2016). They are also known to attack large stands of trees in forested systems (Grégoire et al., 2001; Henin \& Versteirt, 2004; La Spina et al., 2013). In particular, Xylosandrus crassiusculus (Motschulsky) and Xylosandrus germanus (Blandford) comprise two of the most destructive ambrosia beetles of trees growing in ornamental nurseries and tree fruit orchards (Agnello et al., 2015; Ranger et al., 2016). Both X. crassiusculus and $X$. germanus are native to southeast Asia and have become established around the world, including parts of North America, South America, Africa, Europe and Oceania (Rassati et al., 2016; Gallego et al., 2017; Landi, 2017; Gomez et al., 2018; CABI, 2018a, b; Kavčič, 2018). Adult females of $X$. crassiusculus and $X$. germanus tunnel into the heartwood of host trees, where they cultivate fungal gardens of Ambrosiella roeperi T.C. Harr. \& McNew and Ambrosiella grosmanniae C. Mayers, McNew \& T.C. Harr., respectively (Harrington et al., 2014; Mayers et al., 2015). Although $X$. crassiusculus and $X$. germanus attack a broad range of 100-200 trees (Schedl, 1963, Weber \& McPherson, 1983), both species exhibit a narrow preference for living but weakened trees emitting stress-induced ethanol (Ranger et al., 2013, 2015b).

Ethanol acts as a chemical indicator of weakened trees (Kelsey, 2001) and also benefits the colonization success of ambrosia beetles by promoting the growth of their fungal gardens (Ranger et al., 2018). A variety of abiotic and biotic stressors can induce the production and emission of ethanol by trees, including flood and drought stress, frost injury, girdling, impaired root function, root and crown disturbance, pollutants, and pathogens (Kimmerer \& Kozlowski, 1982; Kimmerer \& MacDonald, 1987; Kelsey \& Joseph, 2001; Kelsey et al., 2013; Ranger et al., 2015a). Previous studies have demonstrated that flood stress predisposes trees to attack, and that Xylosandrus spp. can distinguish among trees varying in the tolerance of flooding (Ott, 2007; Ranger et al., 2013, 2015a; Reed et al., 2015). Based on this knowledge, Frank and Ranger (2016) developed a moisture management threshold to help growers avoid overwatering their trees and thereby minimize the risk of ambrosia beetle attacks. Characterizing the role of tree health on host selection and utilization by Xyleborini ambrosia beetles is therefore useful for developing management tactics.

In addition to the role of flood-stress, a growing number of studies suggest that freeze-stressed trees are also preferentially attacked by ambrosia beetles. For example, oak (Quercus rubra L.) trees growing in Germany that showed signs of frost damage but otherwise appeared healthy were attacked by X. germanus (Heidenreich, 1960; Gauss, 1960). Young sycamore (Acer pseudoplatanus L.) trees severely injured or killed by frost were also attacked by X. germanus (Heidenreich, 1960; Gauss, 1960). More recently, La Spina et al. (2013) documented that extreme frost events preceded attacks by $X$. germanus and other ambrosia beetles on large stands of European beech trees, Fagus sylvatica L., in Western Europe. Bark tissues of $F$. sylvatica experimentally-stressed using blocks of dry ice were also more attractive to X. germanus than untreated tissues (La Spina et al., 2013). Freeze stress also preceded attacks on thin-barked deciduous trees growing in ornamental nurseries in northeastern Ohio, U.S.A. (Ranger et al., 2015a).

Based on these previous studies, we hypothesized that deciduous trees subjected to freeze stress would be attacked by opportunistic ambrosia beetles targeting living but weakened trees, such as flood-stressed trees. To test this hypothesis, the present study aimed to: (i) assess the capability of freeze stress to induce attacks by ambrosia beetles; (ii) compare the preference behaviour of ambrosia beetles for freeze-stressed versus flood-stressed trees; and (iii) characterize the time course emission of ethanol from freeze-stressed trees.

\section{Materials and methods}

\section{Imposing freeze stress}

Experiments were conducted in Ohio, U.S.A., and Virginia, U.S.A., because $X$. germanus and $X$. crassiusculus are the predominant exotic ambrosia beetles attacking trees in ornamental nurseries in these two states, respectively. Trees used in the Ohio experiments were $3-4$ years old, $2.54 \mathrm{~cm}$ in diameter, approximately $1.2 \mathrm{~m}$ in height and were grown in $18.9-\mathrm{L}$ pots containing a mixture of $90: 10$ pine bark and sphagnum peat moss, along with lime and Micromax Micronutrients (Scotts Co., Marysville, Ohio). Trees used in the Virginia experiments were approximately 3-4 years old, $2.54 \mathrm{~cm}$ in diameter, approximately $1.2 \mathrm{~m}$ in height and were grown in 28-L pots containing a mixture of aged pine bark and coarse sand (92:8), as well as dolomitic lime to stabilize $\mathrm{pH}$. The media was top dressed with Osmocote Plus 15-9-12 (Scotts Co., Marysville, Ohio) slow-release fertilizer.

For the Ohio experiments, freeze stress was imposed by holding four container-grown Styrax japonicus Sieb. trees overnight (approximately $12 \mathrm{~h}$ ) in a freezer (internal dimensions, length $\times$ width $\times$ height: $76.2 \times 69.9 \times 160.0 \mathrm{~cm}$; model NSPF331WWW/0; Norlake Scientific, Hudson, Wisconsin) programmed to $-10{ }^{\circ} \mathrm{C}$. For the Virginia experiments, freeze stress was imposed by holding container-grown S. japonicus, Cornus florida L. and Cercis canadensis L. trees overnight for three consecutive nights in a commercial cold storage facility maintained at $-10{ }^{\circ} \mathrm{C}$. Trees were relocated outside the cold room during the day and returned in the evening. Malus pumila trees deployed in Virginia were only held overnight in a freezer. After their removal from the freezer, freeze-stressed trees were used for assessing ambrosia beetle host selection (Ohio and Virginia) and the induction of ethanol emissions (Ohio). The deciduous trees S. japonicus, C. florida and C. canadensis were selected for our experiments because previous studies have indicated that freeze stress predisposes them to attack by ambrosia beetles (Ranger et al. 2015b). Similarly, M. pumila was selected because of an intolerance of freeze stress (Cannell \& Smith, 1986; Khanizadehi et al., 1989). We also incorporated these tree species into our experiments because $X$. germanus and $X$. crassiusculus are problematic in ornamental nurseries and tree fruit orchards. 


\section{Preference for freeze-stressed trees}

Free-choice experiments were conducted under field conditions in Ohio and Virginia to assess the host selection behaviour of ambrosia beetles for freeze-stressed and untreated control trees.

Two separate experiments were conducted in Ohio. In both experiments, freeze-stressed $S$. japonicus trees $(n=4)$ were removed from a laboratory freezer after overnight exposure and paired with an untreated control tree $(n=4)$ in a deciduous woodlot in Wayne Co., Ohio $\left(40^{\circ} 45^{\prime} 40.85^{\prime \prime} \mathrm{N}, 81^{\circ} 51^{\prime} 14.71^{\prime \prime} \mathrm{W}\right)$. Freeze-stressed and control trees were spaced $1.5 \mathrm{~m}$ apart with $4 \mathrm{~m}$ between adjacent pairs of trees. Trees were held under field conditions for 8 and 10 days after imposing freeze stress in Experiments 1 and 2 conducted in Ohio, respectively. Attacks on trees were counted at $1,4,7$, and 8 days after imposing freeze stress and field deployment during Experiment 1. Similarly, attacks were counted at 1, 4, 7, 8, and 10 days during Experiment 2. On the last day of field deployment, the trunks were cut at the soil line and transferred to a walk-in cooler stored at $5{ }^{\circ} \mathrm{C}$. Pruning shears were next used to dissect the tunnels/galleries and recover the ambrosia beetle foundresses. Scolytinae specimens were stored in $70 \%$ ethanol and identified to species. Experiment 1 was conducted in Ohio from 10 July 2014 to 18 July 2014 and Experiment 2 was conducted from 29 July 2014 to 11 August 2014.

Two separate field experiments were also conducted in Virginia. In Experiment 1, freeze-stressed S. japonicus $(n=6)$ trees were freeze-stressed for three consecutive nights and then paired with a non-injured tree $(n=6)$ along the edge of a deciduous woodlot in Virginia Beach, Virginia, U.S.A. $\left(36^{\circ} 53^{\prime} 16^{\prime \prime} \mathrm{N}\right.$, $\left.76^{\circ} 10^{\prime} 22^{\prime \prime} \mathrm{W}\right)$. Freeze-stressed and untreated control trees were spaced $3 \mathrm{~m}$ apart with $6 \mathrm{~m}$ between adjacent pairs of trees. Trees were held under field conditions for 10 days after imposing freeze stress in Experiment 1. Attacks on trees were counted at 2, 4, 8, and 10 days after field deployment during Experiment 1. In Experiment 2, freeze-stressed $C$. canadensis $(n=6)$, C. florida $(n=6)$ and $S$. japonicus $(n=6)$ trees were removed from a freezer and arranged in randomized complete blocks with untreated trees of each species ( $n=6$ per species) along the edge of the aforementioned woodlot. A distance of $3 \mathrm{~m}$ was maintained between adjacent trees within a block and $6 \mathrm{~m}$ between adjacent blocks. Attacks on trees were counted at 4, 6, 12 and 14 days after field deployment during Experiment 2. On the last day of field deployment, the trunks were cut at the soil line, transferred to a walk-in cooler and stored at $5{ }^{\circ} \mathrm{C}$. Pruning shears were used to recover the ambrosia beetle foundresses, which were stored in $70 \%$ ethanol and identified to species. Experiment 1 was conducted in Virginia from 2 June 2014 to 12 June 2014 and Experiment 2 was conducted from 26 June 2014 to 10 July 2014.

\section{Comparison between freeze-stressed and flooded trees}

Because previous studies have demonstrated Xylosandrus spp. attack flood-stressed $S$. japonicus and other tree species (Ranger et al., 2013, 2015b), we conducted additional experiments to compare their preference behaviour when given a choice between freeze-stressed versus flood-stressed S. japonicus and M. pumila Mill trees.
Container grown trees were freeze-stressed in accordance with the previously described methods for Ohio and Virginia, except that trees in Virginia were exposed to freeze stress for one night instead of three. Flood stress was imposed using a pot-in-pot system as described by Ranger et al. (2013). Freeze-stressed trees were deployed under field conditions the same day that they were removed from the freezer, whereas flood stress was imposed the same day trees were deployed under field conditions in Ohio and Virginia.

In Ohio, freeze-stressed $(n=12)$, flood-stressed $(n=12)$ and untreated control $(n=12) S$. japonicus trees were deployed in a randomized complete block design within the aforementioned deciduous woodlot in Ohio. A distance of $4 \mathrm{~m}$ was maintained between adjacent trees within a block and $8 \mathrm{~m}$ between adjacent blocks. Because only four container-grown $S$. japonicus trees could fit in the aforementioned freezer used in Ohio, three groups of four freeze-stressed trees were deployed along with flood-stressed and untreated control trees on three separate occasions. Trees were deployed on 1 June 2018 for the first group, on 5 June 2018 for the second group and on 15 June 2018 for the third group. Attacks per tree were counted every 2-3 days. Trees in the first and second groups were cut at the base on 14 June 2018, and trees in the third group were cut at the base on 3 July 2018. Cut trunks were immediately transferred to a walk-in cooler stored at $5{ }^{\circ} \mathrm{C}$.

To compare the host-selection behaviour of ambrosia beetles attacking the freeze-stressed versus flood-stressed trees, we measured the vertical distribution of attacks on the experimentally-stressed trees deployed in Ohio and Virginia. After returning the cut trunks to the laboratory, a ruler was used to measure the distance $(\mathrm{cm})$ from the base of the trunk to each attack, along with noting whether the attacks occurred to the trunk or branches. Ambrosia beetle specimens dissected from the attacked trunks were identified to species. The presence of eggs, larvae and pupae within each gallery was also quantified.

In Virginia, freeze-stressed $(n=8)$, flood-stressed $(n=8)$ and untreated control $(n=8)$ M. pumila trees were used. Trees were deployed in a randomized complete block design within a deciduous woodlot in Virginia Beach, Virginia $\left(36^{\circ} 52^{\prime} 3^{\prime \prime} \mathrm{N}\right.$, $\left.76^{\circ} 17^{\prime} 12^{\prime \prime} \mathrm{W}\right)$. A distance of $3 \mathrm{~m}$ was maintained between adjacent paired trees, and $6 \mathrm{~m}$ between adjacent pairs. Attacks per tree were counted every 2-3 days when trees were deployed from 18 April 2018 to 9 May 2018. The distance of attacks from the base of the trunk were measured $(\mathrm{cm})$ as described above. Ambrosia beetle specimens recovered from the attacked trees were identified to species.

\section{Ethanol emissions}

Time course emissions of ethanol from the bark of freeze-stressed and uninjured S. japonicus trees were examined using solid phase microextraction-gas chromatographymass spectrometry (SPME-GC-MS). Styrax japonicus trees were freeze-stressed in accordance with the method described above for the Ohio location, and then immediately transferred to a greenhouse on the campus of the Ohio Agricultural Research and Development Center. Sampling chambers (Fig. 1) were 

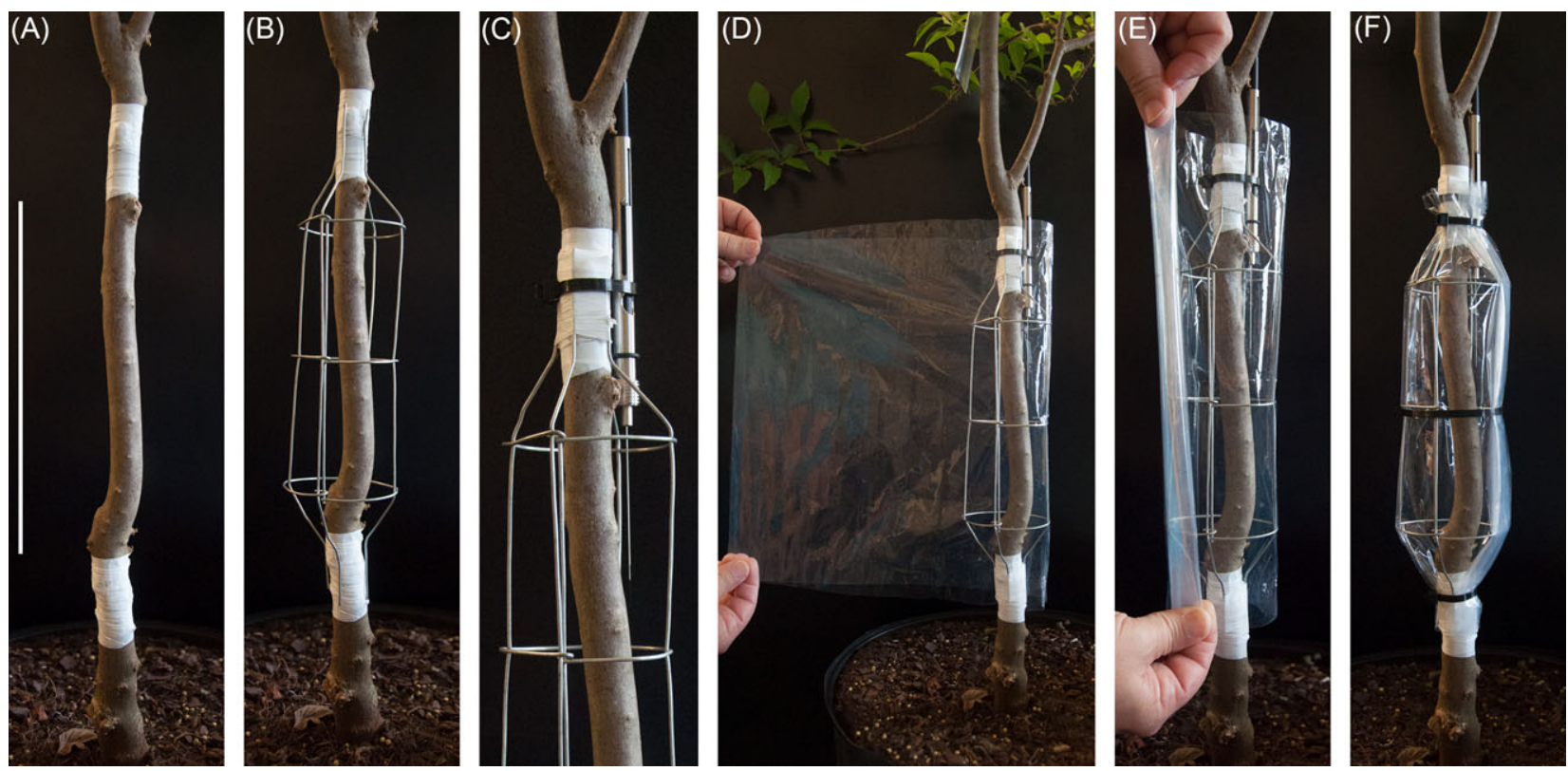

Figure 1 Chamber assembled using a metal frame and Teflon sheet for passively sampling volatile emissions from trunks of Styrax japonicus using solid phase microextraction (SPME)-gas chromatography-mass spectrometry. (A) Chambers were assembled by first wrapping two or three layers of Teflon tape around the trunk (vertical white scale bar $=20 \mathrm{~cm}$ ). (B) A metal support frame was then secured to the trunk using an additional two or three layers of Teflon tape. (C) A syringe containing a retracted SPME fibre was then secured in parallel with the trunk using a zip tie. (D-E) A Teflon sheet was rolled tightly against the chamber. (F) Plastic zip ties were then tightened around the center and both ends of the chamber. For additional details, see Materials and methods. [Colour figure can be viewed at wileyonlinelibrary.com].

placed on the trunks of freeze-stressed and untreated S. japonicus trees to sample for ethanol emissions. Chambers were assembled by first wrapping two or three layers of Teflon tape around the trunk in a 4-5-cm band spaced approximately 21-22 cm apart (Fig. 1A). A metal support frame (diameter $6.5 \mathrm{~cm}$; length $23 \mathrm{~cm}$; volume $763.21 \mathrm{~cm}^{3}$ ) was then secured to the trunk using an additional two or three layers of Teflon tape (Fig. 1B). A syringe containing a retracted SPME fibre (CAR/PDMS; $75 \mu \mathrm{m}$ coating; Sigma-Aldrich, St Louis, Missouri) was next secured in parallel with the trunk using a zip tie (Fig. 1C). The SPME fibre was positioned so the exposed fibre was in parallel with the trunk at a distance of $0.25-0.5 \mathrm{~cm}$ from the bark surface. A Teflon ${ }^{\mathrm{TM}}$ PFA sheet (length $60 \mathrm{~cm}$, width $30 \mathrm{~cm}$; Welch Fluorocarbon Inc., Dover, New Hampshire) was then placed around the chamber and the free ends were rolled together until snug against the metal frame (Fig. 1D, E). Plastic zip ties were tightened around the center and both ends of the chamber (Fig. 1F). Small gaps on either side of the SPME syringe were enclosed using a strip of activated charcoal filter (length $3 \mathrm{~cm}$, width $1 \mathrm{~cm}$; Hunter Fan Company, Tennessee). Because SPME is a passive sampling process, the chamber allowed for volatiles emitted from the bark epidermis (approximately $157 \mathrm{~cm}^{2}$ ) to accumulate in the headspace of the chamber. Assembling a chamber required 4-5 min and could be accomplished by one person. After assembly, the SPME fibre was immediately exposed within the chamber for $3 \mathrm{~h}$ to passively collect volatiles accumulating in the headspace. After sampling, the SPME fibres were retracted into the syringe holder and removed from the chamber. The syringe holders were then disassembled and the SPME fibre assembly was sealed in a capped glass test tube and stored at $-40{ }^{\circ} \mathrm{C}$ until analysis. Ethanol was sampled from freeze-stressed $(n=3)$ and untreated control $(n=3)$ trees on day 0 , before imposing freeze stress on the same day, and then at 1, 4, 8, 11 and 19 days after imposing freeze stress.

For analysis by GC-MS, SPME fibres were thermally desorbed for $2 \mathrm{~min}$ at $250^{\circ} \mathrm{C}$ in the injection port of an Agilent 7890B gas chromatograph (Agilent Technologies, Palo Alto, California) operated in splitless mode from 0-2 min and then a $1: 20$ split for the remainder of the run. A DB-5MS column $(0.25 \mu \mathrm{m} \times 30 \mathrm{~m} \times 0.25 \mu \mathrm{m}$; cross-linked/surface bonded $5 \%$ phenyl, 95\% methylpolysiloxane; Agilent J\&W, Santa Clara, California) was used for analysis: $40-60{ }^{\circ} \mathrm{C}$ at $3{ }^{\circ} \mathrm{C} / \mathrm{min}$ and $60-230^{\circ} \mathrm{C}$ at $20^{\circ} \mathrm{C} / \mathrm{min}$. An Agilent 5977A mass spectrometer was operated in electron impact mode with a scan range of 40-415 amu. The external standard method was used for determining concentrations of ethanol present within the headspace of the chambers (Bartelt, 1997; Romeo, 2009). Serial dilutions containing known amounts of ethanol were applied using a pipette to filter paper discs (diameter $2.5 \mathrm{~cm}$; qualtitative P5, medium porosity; Fisher Scientific, Fair Lawn, New Jersey) placed inside the chamber and sampled using SPME as described above. A glass rod (diameter $2.54 \mathrm{~cm}$ ) was used in replacement of a tree stem within the sampling chamber. Peak areas associated with the ethanol standards were measured and a standard concentration curve was used to determine concentrations of ethanol associated with the trunk tissues. Fibres were conditioned before sampling by exposure within 


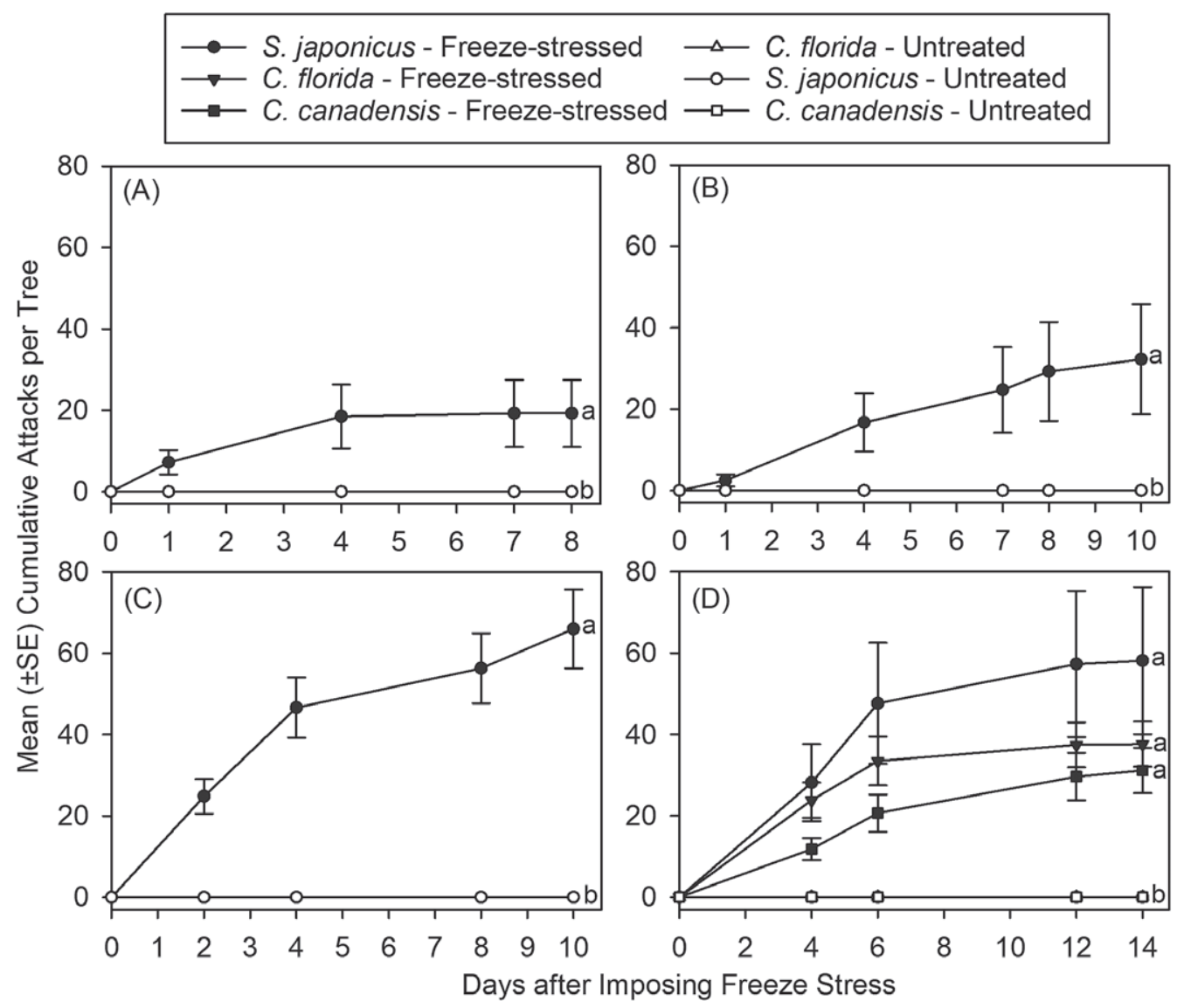

Figure 2 Cumulative ambrosia beetle attacks on freeze-stressed and untreated control trees. (A, B) Styrax japonicus deployed in Ohio. (C, D) Styrax japonicus, Cornus florida and Cercis canadensis deployed in Virginia. Different lowercase letters indicate significant differences in mean $\pm S E$ total attacks per tree. (A) $t=4.93$; d.f. $=6 ; P=0.003$; (B) $t=4.45$; d.f. $=6 ; P=0.004$; (C) $t=30.74$; d.f. $=10 ; P<0.0001$; and (D) $F=154.66$; d.f. $=5$, 30; $P<0.0001$.

the injection port for $20 \mathrm{~min}$ at $250^{\circ} \mathrm{C}$. In all cases prior to sampling, Teflon sheets and steel chambers were heated in an oven for $2 \mathrm{~h}$ at $37^{\circ} \mathrm{C}$.

\section{Statistical analysis}

For the experiments concerning the preference for freezestressed trees, an unpaired $t$-test $(\alpha=0.05)$ was used to compare the number of attacks per tree on freeze-stressed versus untreated control $S$. japonicus trees as part of both experiments conducted in Ohio (SAS Institute, 2001). An unpaired $t$-test was also used to compare attacks to trunks versus branches on freeze-stressed $S$. japonicus trees deployed in Ohio, along with the number of $X$. germanus and Anisandrus maiche specimens recovered from the trunks versus branches. Similarly, an unpaired $t$-test was used to compare the number of attacks on freeze-stressed versus untreated control $S$. japonicus trees deployed as part of the first experiment conducted in Virginia. A one-way analysis of variance (ANOVA) and Tukey's honestly significant difference (HSD) was used to compare the number of attacks on freeze-stressed and uninjured $C$. canadensis, C. florida and S. japonicus trees deployed as part of the second experiment conducted in Virginia. An unpaired $t$-test was used to compare the number of
$X$. crassiusculus versus $X$. germanus specimens recovered from freeze-stressed $C$. canadensis as part of Experiment 1 and $C$. canadensis, C. florida and S. japonicus trees deployed as part of Experiment 2 in Virginia.

For the experiments concerning the comparison between freeze-stressed and flooded trees, an unpaired $t$-test $(\alpha=0.05)$ was used to compare the number of attacks on freeze-stressed versus flood-stressed $S$. japonicus trees deployed in Ohio, and also Virginia. A correlation analysis was used to assess the relationship between freeze stress and flood stress on the vertical distribution of attacks (SAS Institute, 2001). Furthermore, the Kolmogorov-Smirnov two-sample test was used to compare the vertical distribution of ambrosia beetle attacks on freeze-stressed versus flood-stressed trees (SAS Institute, 2001). An unpaired $t$-test was used to separately compare the number of $A$. maiche Stark versus $X$. germanus adults, eggs and larvae recovered from freeze-stressed and flood-stressed $S$. japonicus trees deployed in Ohio. According to the species of ambrosia beetles, an unpaired $t$-test was also used to compare the number A. maiche or $X$. germanus adults, eggs and larvae recovered from freeze-stressed versus flood-stressed trees deployed in Ohio. A one-way ANOvA and Tukey's HSD were used to separately compare the number of ambrosia beetle adults recovered from freeze-stressed and flood-stressed M. pumila trees deployed in Virginia. According 
Table 1 Ambrosia beetle attacks and specimens dissected from freeze-stressed Styrax japonicus trees deployed in Ohio

\begin{tabular}{|c|c|c|c|c|c|c|c|c|c|}
\hline \multirow[b]{3}{*}{ Experiment } & \multicolumn{9}{|c|}{ Mean \pm SE per tree } \\
\hline & \multicolumn{3}{|l|}{ Total attacks ${ }^{a}$} & \multicolumn{3}{|c|}{ Xylosandrus germanus } & \multicolumn{3}{|c|}{ Anisandrus maiche } \\
\hline & Trunk & Branches & $t, P$ & Trunk & Branches & $t, P$ & Trunk & Branches & $t, P$ \\
\hline $1^{b}$ & $9.5 \pm 2.9 a$ & $12.0 \pm 7.0 \mathrm{a}$ & $2.44,0.55$ & $2.8 \pm 1.8 \mathrm{a}$ & $11.3 \pm 7.0 \mathrm{a}$ & $0.63,0.55$ & $0.0 \pm 0.0$ & $0.0 \pm 0.0$ & - \\
\hline $2^{b}$ & $12.5 \pm 12.5 \mathrm{a}$ & $23.0 \pm 9.4 a$ & $2.45,0.53$ & $4.8 \pm 4.8 a$ & $16.8 \pm 6.4 a$ & $1.78,0.13$ & $0.3 \pm 0.3 a$ & $1.0 \pm 0.4 a$ & $1.56,0.17$ \\
\hline
\end{tabular}

${ }^{a}$ No attacks occurred on untreated S. japonicus (data not included).

${ }^{b}$ Different lowercase letters within a row indicate significantly different means for total attacks and excavated specimens between trunks versus branches in Experiments 1 and 2 (d.f. $=6$ for all comparisons).

Table 2 Ambrosia beetles dissected from freeze-stressed Styrax japonicus, Cornus florida and Cercis canadensis trees deployed in Virginia

\begin{tabular}{|c|c|c|c|c|c|c|c|c|c|}
\hline \multirow[b]{3}{*}{ Experiment } & \multicolumn{9}{|c|}{ Mean \pm SE per tree } \\
\hline & \multicolumn{3}{|l|}{ Styrax japonicus } & \multicolumn{3}{|l|}{ Cornus florida ${ }^{a}$} & \multicolumn{3}{|c|}{ Cercis canadensis ${ }^{a}$} \\
\hline & X. crassiusculus & $X$. germanus & $t, P$ & X. crassiusculus & $X$. germanus & $t, P$ & X. crassiusculus & $X$. germanus & $t, P$ \\
\hline $1^{b}$ & $27.0 \pm 3.6 \mathrm{a}$ & $0.3 \pm 0.2 b$ & $\begin{array}{l}15.1 \\
<0.0001\end{array}$ & - & - & & - & - & \\
\hline $2^{b}$ & $22.2 \pm 6.0 \mathrm{a}$ & $0.2 \pm 0.2 b$ & $\begin{array}{l}8.97 \\
<0.0001\end{array}$ & $18.7 \pm 6.3 \mathrm{a}$ & $0.0 \pm 0.0 b$ & $\begin{array}{l}6.35 \\
<0.0001\end{array}$ & $5.4 \pm 1.2 \mathrm{a}$ & $0.0 \pm 0.0 b$ & $\begin{array}{l}9.35 \\
<0.0001\end{array}$ \\
\hline
\end{tabular}

aCornus florida and C. canadensis were not tested in Experiment 1, as indicated by '-'.

${ }^{b}$ Different lowercase letters indicate significantly different means between Xylosandrus crassiusculus and Xylosandrus germanus recovered from S. japonicus within an experiment ( $t$-test; d.f. $=10$ for all comparisons).

to the species of ambrosia beetles, an unpaired $t$-test was also used to compare the number adults, eggs and larvae recovered from freeze-stressed versus flood-stressed trees deployed in Virginia.

Repeated measures ANOVA was used to compare the emission of ethanol from freeze-stressed $S$. japonicus trees over time (SAS Institute, 2001). Count data were $\log (x+1)$ transformed prior to analysis but untransformed data are presented.

\section{Results}

\section{Preference for freeze-stressed trees}

Ambrosia beetles preferentially attacked freeze-stressed $S$. japonicus trees over untreated control trees during two experiments conducted in Ohio (Fig. 2A, B). In Experiment 1, ambrosia beetle attacks on $S$. japonicus were detected 1 day after imposing freeze stress (Fig. 2A). By day 8, a mean \pm SE of $22.5 \pm 9.6$ attacks per tree was recorded on freeze-stressed $S$. japonicus, whereas no attacks occurred on the untreated control trees. There was no difference in the mean number of attacks that occurred to the trunks versus branches of freeze-stressed $S$. japonicus (Table 1). In Experiment 2, ambrosia beetle attacks on $S$. japonicus were also initiated 1 day after imposing freeze stress (Fig. 2B). A mean of $37.3 \pm 17.7$ attacks per tree occurred by day 10 , whereas no attacks occurred on the untreated control $S$. japonicus trees. No difference was detected in the number of attacks that occurred to the trunks versus branches of freeze-stressed S. japonicus trees (Table 1).

During the two free-choice experiments conducted in Virginia ambrosia beetles preferentially attacked freeze-stressed deciduous trees deployed under field conditions (Fig. 2C, D). In Experiment 1 , a mean \pm SE of $31.5 \pm 13.6$ attacks per tree occurred by day 10 to freeze-stressed $S$. japonicus trees, whereas no attacks occurred on the untreated control trees (Fig. 2C). In Experiment 2, a mean of $58.2 \pm 18.1$ attacks per $S$. japonicus tree, $37.7 \pm 5.6$ attacks per $C$. florida tree and $31.2 \pm 5.6$ attacks per $C$. canadensis tree were recorded at 14 days after imposing freeze stress (Fig. 2D). There was no difference in cumulative attacks among freeze-stressed C. canadensis, C. florida and S. japonicus trees, although there was a significant difference compared with the $0.0 \pm 0.0$ attacks on the untreated control trees (Fig. 2D).

In total, $54 \mathrm{X}$. germanus specimens were recovered from the freeze-stressed S. japonicus trees attacked during Experiment 1 in Ohio; no other Scolytinae species were recovered (Table 1). A mean $\pm \mathrm{SE}$ of $13.5 \pm 6.4 \mathrm{X}$. germanus were recovered per freeze-stressed S. japonicus. There was no difference in the number of $X$. germanus specimens recovered from trunks versus branches during Experiment 1 (Table 1). In total, 86 X. germanus and five Anisandrus maiche Stark were recovered from the freeze-stressed S. japonicus trees deployed during Experiment 2 in Ohio (Table 1). A mean of 21.5 $\pm 9.5 \mathrm{X}$. germanus specimens was recovered per freeze-stressed $S$. japonicus compared with $1.3 \pm 0.5$ A. maiche per tree $(t=2.57$; d.f. $=6 ; P=0.043)$. There was no difference in the number of $X$. germanus or $A$. maiche specimens recovered from trunks versus branches during Experiment 2 (Table 1).

In total, $162 X$. crassiusculus and $2 X$. germanus were recovered from freeze-stressed S. japonicus trees deployed during Experiment 1 in Virginia (Table 2). Similarly, 133 X. crassiusculus and $1 X$. germanus were recovered from freeze-stressed S. japonicus deployed during Experiment 2 (Table 2). In total, 112 and $40 \mathrm{X}$. crassiusculus specimens were recovered from 

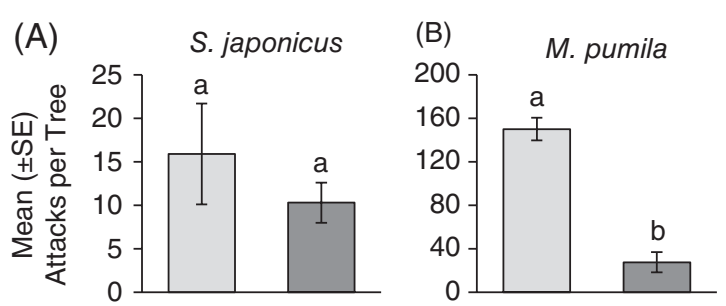

Figure 3 Mean \pm SE cumulative attacks on freeze-stressed versus flood-stressed (A) Styrax japonicus deployed in Ohio and (B) Malus pumila deployed in Virginia. No attacks occurred on untreated control trees (data not shown). Different lowercase letters indicate significantly different means within a trees species. (A) $t=0.31$; d.f. $=22 ; P=0.76$ and (B) $t=3.99 ;$ d.f. $=14 ; P=0.0013$.

freeze-stressed $C$. florida and $C$. canadensis trees deployed during Experiment 2 in Virginia, respectively (Table 2). No X. germanus were recovered from freeze-stressed $C$. florida or $C$. canadensis trees.

\section{Comparison between freeze-stressed and flooded trees}

Ambrosia beetle host-selection and preference behaviour were compared when given a choice between freeze-stressed versus flood-stressed trees deployed in Ohio and Virginia. Under free-choice conditions, ambrosia beetles attacked both freeze-stressed and flood-stressed trees deployed in Ohio and Virginia. In Ohio, there was no difference in the mean $\pm \mathrm{SE}$ of $17.1 \pm 6.2$ attacks per freeze-stressed $S$. japonicus tree compared with the $10.3 \pm 2.3$ attacks per flood-stressed tree (Fig. 3A). In Virginia, a mean of $154.6 \pm 10.9$ attacks occurred per freeze-stressed $M$. pumila tree, which was higher than the $28.8 \pm 6.7$ attacks per flood-stressed tree (Fig. 3B).

Because ambrosia beetles were observed to attack the branches of $S$. japonicus during the previously described experiments concerning the preference for freeze-stressed trees, we compared the vertical distribution of attacks on freeze-stressed versus flood-stressed trees. A significant difference was detected in the vertical distribution of ambrosia beetle attacks on freeze-stressed versus flood-stressed S. japonicus trees deployed in Ohio (Kolmogorov-Smirnov two-sample test; $P<0.0001$ ) (Fig. 4A, B). Attacks on flood-stressed S. japonicus trees were skewed towards the lower portion of the trunk, whereas attacks on freeze-stressed S. japonicus mainly occurred around the middle to upper regions of the trunk and extended into the branches (Fig. 4A, B).

A significant difference was also detected in the vertical distribution of ambrosia beetle attacks on freeze-stressed versus flood-stressed $M$. pumila trees deployed in Virginia (Kolmogorov-Smirnov two-sample test; $P<0.0001$ ) (Fig. 4C, D). Attacks on flood-stressed M. pumila trees were skewed towards the lower portion of the trunk, whereas attacks on freeze-stressed $M$. pumila trees mainly occurred around the middle to upper regions of the trunk and extended into the branches (Fig. 4C, D).

In Ohio, A. maiche and X. germanus followed by Xyleborinus saxesenii were the most abundant Scolytinae dissected from freeze-stressed $S$. japonicus trees (Table 3). In particular, 65 A. maiche, $66 \mathrm{X}$. germanus and one $X$. saxesenii were recovered from the freeze-stressed trees. Similarly, A. maiche and $X$. germanus were the two most abundant species dissected from the flood-stressed $S$. japonicus trees (Table 3). In total, 47 A. maiche, 34 X. germanus, two Monarthrum mali (Fitch) and one Anisandrus sayi (Hopkins) were recovered from the flood-stressed trees. Eggs and larvae of A. maiche and X. germanus were present in galleries created in the freeze-stressed and flood-stressed S. japonicus trees (Table 3). No pupae were recovered from the freeze-stressed or flood-stressed trees. There was no difference in the number of $A$. maiche versus $X$. germanus adults, eggs and larvae recovered from freeze-stressed $S$. japonicus or from flood-stressed S. japonicus (Table 3). Significantly more A. maiche larvae were recovered from freeze-stressed versus flood-stressed $S$. japonicus trees $(t=2.220$; d.f. $=22$; $P=0.039)$, although there was no difference in the number of $A$. maiche adults $(t=0.21 ;$ d.f. $=22 ; P=0.84)$ and eggs $(t=0.59$; d.f. $=22 ; P=0.57)$. There was no difference in the number of $X$. germanus adults $(t=0.74$; d.f. $=22 ; P=0.47)$, eggs $(t=0.21$; d.f. $=22 ; P=0.84)$ and larvae $(t=0.75 ;$ d.f. $=22 ; P=0.46)$ recovered from freeze-stressed versus flood-stressed $S$. japonicus trees deployed in Ohio (Table 3). There was no difference in the mean $\pm \mathrm{SE}$ proportion of galleries per tree containing pooled adult ambrosia beetle specimens for freeze-stressed $(0.68 \pm 0.07)$ versus flood-stressed trees $(0.53 \pm 0.11)(t=1.56$; d.f. $=22 ; P=0.13)$, the proportion of galleries containing eggs for freeze-stressed $(0.04 \pm 0.02)$ versus flood-stressed trees $(0.07 \pm 0.02)(t=0.56 ;$ d.f. $=22 ; P=0.58)$ or the proportion of galleries containing larvae for freeze-stressed $(0.06 \pm 0.03)$ versus flood-stressed trees $(0.01 \pm 0.01)(t=1.70 ;$ d.f. $=22$; $P=0.10)$.

In Virginia, X. crassiusculus was the most abundant Scolytinae dissected from freeze-stressed $M$. pumila trees, followed by seven other species, namely $X$. germanus, Cnestus mutilatus (Blandford), Hypothenemus dissimilis Zimmermann, Ambrosiodmus rubricolis (Eichhoff), Xylosandrus compactus Eichhoff, X. saxesenii (Ratzeburg) and Hypothenemus eruditus Westwood (Table 4). Similarly, X. crassiusculus was the most abundant Scolytinae species recovered from flood-stressed M. pumila trees, followed by X. germanus, A. rubricolis and C. mutilatus (Table 4). Significantly more $X$. crassiusculus $(t=6.02 ;$ d.f. $=14 ; P<0.0001), X$. saxesenii $(t=4.08 ;$ d.f. $=14$; $P=0.002)$ and $H$. dissimilis $(t=3.18 ;$ d.f. $=14 ; P=0.008)$ were recovered from the freeze-stressed versus flood-stressed $M$. pumila trees deployed in Virginia, although no difference was detected for $X$. germanus $(t=1.36$; d.f. $=14 ; P=0.20), C$. mutilatus $(t=0.93$; d.f. $=14 ; P=0.37), H$. eruditus $(t=0.83$; d.f. $=14 ; P=0.42)$, A. rubricolis $(t=1.41 ;$ d.f. $=14 ; P=0.19)$ and $X$. compactus $(t=0.97$; d.f. $=14 ; P=0.42)$ (Table 4$)$. A significantly higher proportion of galleries per tree created in freeze-stressed $M$. pumila trees $(0.73 \pm 0.03)$ contained ambrosia beetle foundresses (pooled across species) compared with the flood-stressed trees $(0.44 \pm 0.11)(t=2.61 ;$ d.f. $=14 ; P=0.021)$.

\section{Stress-induced ethanol emissions}

Time course emissions of ethanol from the trunks of freeze-stressed and untreated control $S$. japonicus were 

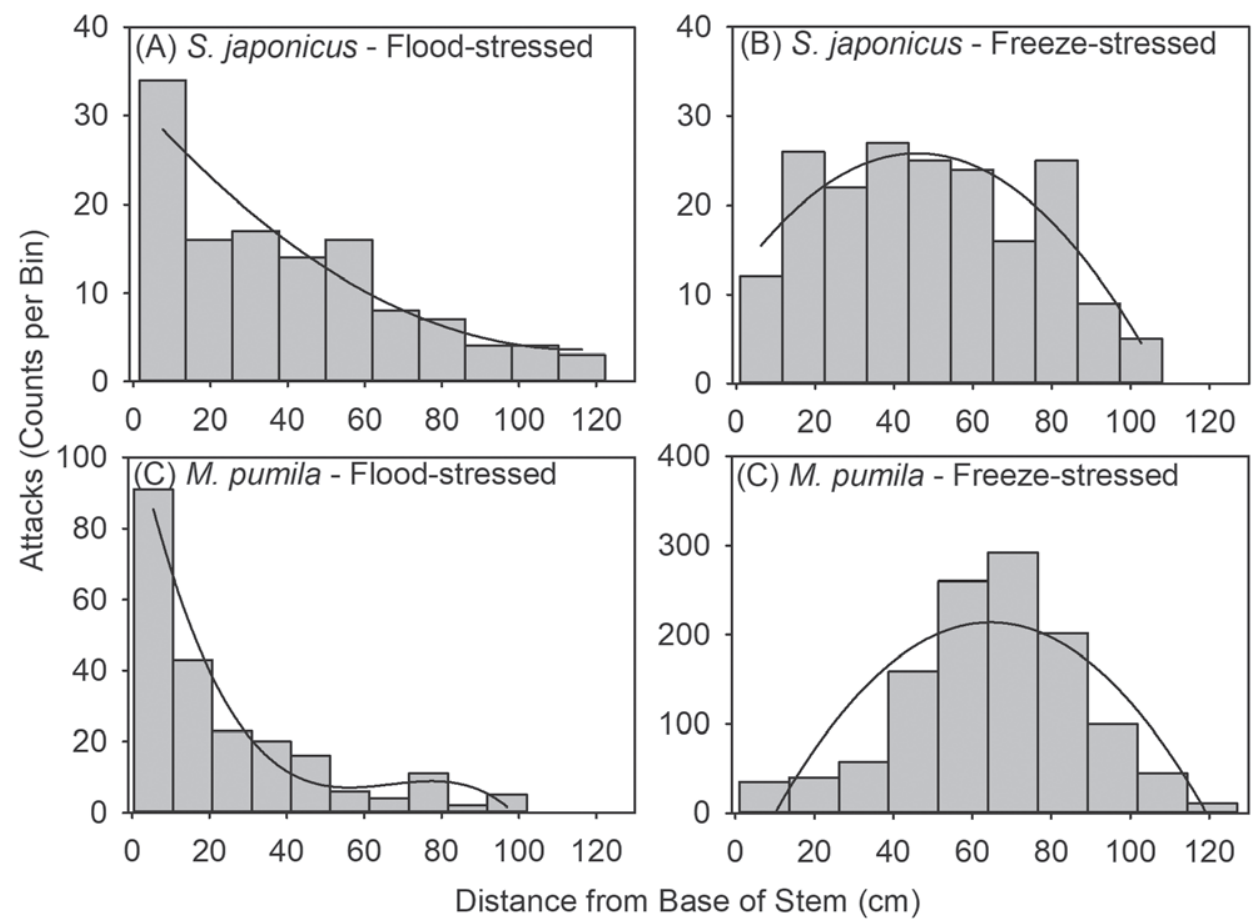

Figure 4 Histogram analysis of the vertical distribution of attacks on freeze-stressed and flood-stressed (A, B) Styrax japonicus deployed in Ohio and (C, D) Malus pumila deployed in Virginia. Ten bins were used to group attacks for each trees species and treatment. $(A) r^{2}=0.86 ; F=21.70 ;$ d.f. $=2,7$; $P=0.001 ;(\mathrm{B}) r^{2}=0.74 ; F=10.10 ;$ d.f. $=2,7 ; P=0.009 ;(\mathrm{C}) r^{2}=0.96 ; F=47.92 ;$ d.f. $=2,7 ; P=0.0001 ;$ and (D) $r^{2}=0.74 ; F=9.75 ;$ d.f. $=2,7 ; P=0.01$.

Table 3 Ambrosia beetles recovered from Styrax japonicus trees deployed in Ohio to compare preference for freeze-stressed versus flood-stressed trees

\begin{tabular}{|c|c|c|c|c|}
\hline \multirow[b]{2}{*}{ Treatment } & \multirow[b]{2}{*}{ Life stage } & \multicolumn{3}{|c|}{ Mean \pm SE specimens per tree } \\
\hline & & Anisandrus maiche & Xylosandrus germanus & $t ; P^{a}$ \\
\hline \multirow[t]{4}{*}{ Freeze } & Adults & $5.4 \pm 2.7 a$ & $5.5 \pm 2.9 \mathrm{a}$ & $0.01 ; 0.99$ \\
\hline & Eggs & $5.1 \pm 4.0 \mathrm{a}$ & $10.8 \pm 6.5 a$ & $0.42 ; 0.68$ \\
\hline & Larvae & $19.7 \pm 10.4 a$ & $4.0 \pm 2.7 \mathrm{a}$ & $1.05 ; 0.30$ \\
\hline & Pupae & $0.0 \pm 0.0$ & $0.0 \pm 0.0$ & - \\
\hline \multirow[t]{4}{*}{ Flood } & Adults & $3.9 \pm 1.3 \mathrm{a}$ & $2.8 \pm 1.1 \mathrm{a}$ & $0.59 ; 0.56$ \\
\hline & Eggs & $1.8 \pm 1.4 \mathrm{a}$ & $5.3 \pm 2.8 a$ & $0.82 ; 0.43$ \\
\hline & Larvae & $0.0 \pm 0.0 \mathrm{a}$ & $1.1 \pm 1.1 \mathrm{a}$ & $1.00 ; 0.33$ \\
\hline & Pupae & $0.0 \pm 0.0$ & $0.0 \pm 0.0$ & - \\
\hline
\end{tabular}

${ }^{a}$ Different lowercase letters within a row indicate significantly different means ( $t$-test; d.f. $=22$ for all comparisons). No attacks occurred on the uninjured trees and they were not included in the analysis.

characterized using SPME-GC-MS (Figs 1 and 5). A significant repeated measures within-treatment effect was detected in the emission of ethanol from the freeze-stressed trees $(F=22.49$; d.f. $=5,10 ; P=0.0087)$. Ethanol emissions were not detected on day 0 before inducing freeze stress, although a mean \pm SE of $4.31 \pm 2.36 \mathrm{ng}$ of ethanol $/ \mathrm{cm}^{2} / \mathrm{h}$ was detected 1 day after freeze stress (Fig. 5). Ethanol emissions increased to $570.52 \pm 198.76 \mathrm{ng}$ of ethanol $/ \mathrm{cm}^{2} / \mathrm{h}$ and $395.66 \pm 148.51 \mathrm{ng}$ of ethanol $/ \mathrm{cm}^{2} / \mathrm{h}$ by days 4 and 8 , respectively. By day 11 , ethanol emissions decreased to $42.41 \pm 13.56 \mathrm{ng}$ of ethanol $/ \mathrm{cm}^{2} / \mathrm{h}$ and, by day 19 , ethanol emissions decreased to $13.07 \pm 11.18 \mathrm{ng}$ of ethanol $/ \mathrm{cm}^{2} / \mathrm{h}$ (Fig. 5). Overall, ethanol emissions were significantly higher on day 4 after imposing freeze stress compared with day 1 and days 11 and 19 (Fig. 5). No ethanol emissions were detected from the bark of untreated control S. japonicus (data not included).

\section{Discussion}

Low temperature stress is one of the most important factors affecting the production of horticultural crops (Ashworth, 1992). Freeze injury is generally the result of a rapid drop in temperature below freezing after warm or mild weather during autumn, winter or spring months (Schoeneweiss, 1975; Burke et al., 1976). This scenario can occur at relatively small scales affecting a few individual trees (Motzkin et al., 2002; Ranger et al., 2015a) or at a regional scale affecting large stands of trees 
Table 4 Ambrosia beetles recovered from freeze-stressed and flood-stressed Malus pumila trees deployed in Virginia

\begin{tabular}{|c|c|c|c|c|c|c|c|c|}
\hline \multirow[b]{2}{*}{ Treatment } & \multicolumn{8}{|c|}{ Mean \pm SE Scolytinae adults ${ }^{a}$ per tree } \\
\hline & $X_{C r}$ & $X g$ & Xs & $H d$ & $\mathrm{Cm}$ & $\mathrm{He}$ & $\operatorname{Ar}$ & Xco \\
\hline $\begin{array}{l}\text { Freeze }^{b} \\
\text { Flood }^{b}\end{array}$ & $\begin{array}{l}108.6 \pm 8.9 \mathrm{a} \\
18.8 \pm 8.1 \mathrm{a}\end{array}$ & $\begin{array}{l}3.9 \pm 0.7 b \\
2.5 \pm 1.0 b\end{array}$ & $\begin{array}{l}1.8 \pm 0.5 b c \\
0.0 \pm 0.0 c\end{array}$ & $\begin{array}{l}1.5 \pm 0.5 \mathrm{~cd} \\
0.0 \pm 0.0 \mathrm{c}\end{array}$ & $\begin{array}{l}0.5 \pm 0.3 \mathrm{~cd} \\
0.2 \pm 0.2 \mathrm{c}\end{array}$ & $\begin{array}{l}0.3 \pm 0.3 d \\
0.0 \pm 0.0 c\end{array}$ & $\begin{array}{l}0.3 \pm 0.2 d \\
1.0 \pm 0.5 b c\end{array}$ & $\begin{array}{l}0.3 \pm 0.3 d \\
0.0 \pm 0.0 c\end{array}$ \\
\hline
\end{tabular}

${ }^{a} X \mathrm{Cr}=X y l o s a n d r u s$ crassiusculus, $\mathrm{Xg}=X y l o s a n d r u s$ germanus, $\mathrm{Xs}=$ Xyleborinus saxesenii, $\mathrm{Hd}=$ Hypothenemus dissimilis, Cm=Cnestus mutilatus, $\mathrm{He}=$ Hypothenemus eruditus, $\mathrm{Ar}=$ Ambrosiodmus rubricolis and $X_{C O}=X y l o s a n d r u s ~ c o m p a c t u s . ~-$, specimens not recovered from flood-stressed trees. ${ }^{b}$ Different lowercase letters within a row indicate significant differences by one-way analysis of variance and Tukey's honestly significant difference (Freeze: $F=93.78 ;$ d.f. $=7,56 ; P<0.0001$; Flood: $F=20.84 ;$ d.f. $=7,56 ; P<0.0001$ ).

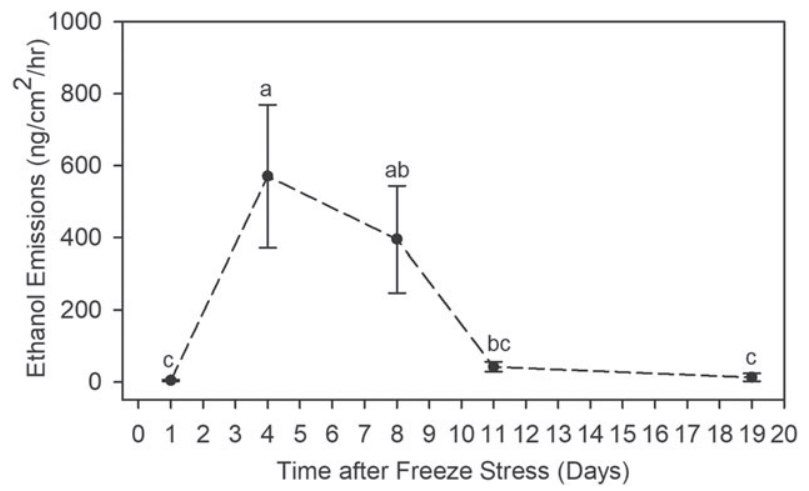

Figure 5 Mean \pm SE time course emissions of ethanol by solid phase microextraction-gas chromatography-mass spectrometry from trunks of freeze-stressed Styrax japonicus. No ethanol was detected in emissions from untreated control trees or from S. japonicus prior to initiating freeze stress (data not included). Different lowercase letters indicate significant within-treatment differences in ethanol emissions by freeze-stressed trees (repeated measures analysis of variance: $F=11.32$; d.f. $=4,8$; $P=0.0022$; followed by one-way analysis of variance and Tukey's honestly significant difference: $F=12.22 ;$ d.f. $=4,10 ; P=0.0007$ ).

(La Spina et al., 2013; Kosiba et al., 2018; Vitasse \& Rebetez, 2018). Trees injured by freezing can then be predisposed to attack by secondary wood-boring insects (Solomon, 1995; Moraal \& Hilszczanski, 2000; Vansteenkiste et al., 2004). The present study provides one of the few examples of ambrosia beetles attacking experimentally freeze-stressed deciduous trees, in addition to demonstrating the emission of stress-induced ethanol from trunks of injured trees. Most attacks were by non-native Xyleborini species that rapidly attacked the freeze-stressed trees. Targeting trees in the early stages of physiological stress might contribute to the invasion success of Xyleborini ambrosia beetles that utilize living but weakened trees (Kühnholz et al., 2001; Ranger et al., 2015a).

Freeze-stressed trees were rapidly attacked during the present study, with attacks often beginning within 1-2 days after injury. Ambrosia beetles have also been observed to begin attacking flood-stressed trees within 1-2 days after flooding (Ranger et al., 2013, 2015b). Xylosandrus germanus was one of the predominant species excavated from freeze-stressed trees deployed in Ohio, whereas $X$. crassiusculus was the predominant species recovered in Virginia. The present study also documents the recovery of $A$. maiche from stressed trees deployed in Ohio. Notably, A. maiche was one of the predominant species recovered along with $X$. germanus when beetles were allowed to freely choose between freeze-stressed and flood-stressed trees. After first being reported from North America in 2009, A. maiche now appears to be established in eight states within the Midwestern and Eastern U.S.A. (Rabaglia et al., 2009; Atkinson, 2018). Successful colonization of freeze-stressed and flood-stressed trees, as made evident by the presence of eggs and larvae within galleries, was documented for $A$. maiche and $X$. germanus during the present study. These results provide additional insight into the utilization of trees in the early stages of physiological stress by certain Xyleborini ambrosia beetles.

By measuring the vertical distribution of attacks, ambrosia beetles were demonstrated to preferentially attack the lower trunk region on flood-stressed trees, whereas attacks on freeze-stressed trees mainly occurred around the middle and upper trunk regions and branches. Heidenreich (1960) also observed that trunks and branches of freeze-stressed trees were attacked by $X$. germanus, whereas trunks are mainly attacked on flood-stressed trees (Ranger et al., 2016). Understanding how physiological stressors influence the vertical distribution of ambrosia beetle attacks could aid tree care professionals in determining what stressors potentially predisposed the trees to attack, thereby helping to predict and mitigate the risk of future attacks. Although not confirmed, we hypothesize the difference in distribution of attacks on freeze-stressed versus flood-stressed trees corresponds to the presence of ethanol within these tissues. Kelsey et al. (2013) demonstrated that more than four-fold ambrosia beetle attacks occurred above ethanol-infused sapwood tissues compared with the opposite side of the same log that did not any receive ethanol treatment.

Gara et al. (1993) used a stainless steel chamber to detect ethanol emissions from the bark of lodgepole pine [Pinus contorta murrayana (Grev. and Balf) Engelm]. trees infected with heartwood decay fungi. The wire frame and Teflon-base chambers used as part of the present study allowed for the confirmation and measurement of ethanol emissions from the bark of freeze-stressed trees.

When cellular oxygen levels decline and are depleted, anaerobic respiration results in pyruvic acid being converted into acetaldehyde, which is then reduced to ethanol (Fall, 1999). Alcoholic fermentation typically occurs in the roots of plants or trees in response to flooding (Fall, 1999). Ethanol and acetaldehyde are not only then secreted by the roots, but also enter the transpiration stream and are subsequently emitted from the bark epidermis and the leaves (Kimmerer \& Kozlowski, 1982; MacDonald \& Kimmerer, 1993; Ranger et al., 2013, 2015b). By contrast, an inability to uptake $\mathrm{O}_{2}$ by cells within trunks injured by freeze stress would also lead to the production and emission of 
ethanol from these tissues (Kimmerer \& Kozlowski, 1982; Forney et al., 2000; Obenland et al., 2003).

As noted previously, the presence of ethanol within host tree tissues benefits fungiculture by $X$. germanus and other ambrosia beetles by promoting the growth of the fungal symbiont and suppressing the growth of other fungal competitors (Ranger et al., 2018). Because foundress ambrosia beetles do not begin laying eggs until the fungal gardens are established, the presence of ethanol within the host tree tissues indirectly benefits the colonization success of these opportunistic ambrosia beetles. Healthy trees baited with an ethanol lure were not included as a positive control as part of the present study. However, Ranger et al. (2018) previously demonstrated that healthy C. canadensis and $C$. florida trees baited with ethanol lures were attacked but no fungal gardens or offspring were produced in the absence of in vivo ethanol within the host tree tissues. Still, additional studies are warranted to determine whether other compounds besides ethanol within the host tree tissues are beneficial to ambrosia beetle fungiculture and their colonization success.

A warming climate with a continued risk of freeze stress could result in increased attacks by Xyleborini ambrosia beetles, particularly for intolerant trees growing in ornamental nurseries and tree fruit orchards. Unusually warm periods followed by wide-spread freeze stress of trees have recently been reported for the U.S.A. and Europe (Ningre \& Colin, 2007; Gu et al., 2008; Augspurger, 2009; Hufkens et al., 2012; Timlin et al., 2012; Kosiba et al., 2018; Vitasse \& Rebetez, 2018). An increase in global temperatures is anticipated to promote earlier plant development, although an increased risk of spring freeze injury has also been predicted even if the frequency and severity of late spring frosts remains the same (Hänninen, 1991; Arora, 2018; Vitasse et al., 2018). Wild trees growing within their natural distribution ranges rarely experience severe frost injury (Vitasse et al., 2018), although trees growing in ornamental nurseries and tree fruit orchards will likely be vulnerable to attack. Trees being grown outside their normal distribution or the loss of freeze tolerance traits resulting from selective breeding programmes would contribute to the risk of injury and subsequent ambrosia beetle attacks.

For example, a mild winter that occurred in northeastern Ohio in 2011-2012 resulted in trees budding up to 1 month earlier than normal (Timlin et al., 2012; NOAA, 2012). Vulnerable root and vegetative tissues were then exposed to six below freezing events that occurred in the region in April 2012. Ambrosia beetle attacks on trees growing in ornamental nurseries were subsequently documented in May 2012 after the spring flight of overwintering adults had commenced (Ranger et al., 2015a). Thin-barked deciduous trees with known intolerance of freeze stress were attacked, namely Acer palmatum Thunb., C. canadensis, Cladrastis kentukea (Dum.-Cours.) Rudd, S. japonicus and Zelkova serrata (Thunb.) Makino (Cappiello \& Littlefield, 1994; Boerner et al., 1988; Brand, 2002; Reed, 2005; Ranger et al., 2015a). In support of these field observations, the present study demonstrated that experimentally-stressed C. canadensis, C. florida, M. pumila and S. japonicus were attacked by non-native ambrosia beetles. La Spina et al. (2013) previously reported that experimentally freeze-stressed tissues of $F$. sylvatica also attracted and induced attacks by $X$. germanus and other ambrosia beetles.
In summary, in the present study, we have demonstrated that freeze stress predisposes thin-barked deciduous trees to attack by opportunistic ambrosia beetles, especially $X$. crassiusculus and $X$. germanus. Both of these species are strongly attracted to trees emitting stress-induced ethanol, and freeze stress of $S$. japonicus was demonstrated to induce the emission of ethanol. The results of the present study indicate that trees intolerant of freeze stress growing in ornamental nurseries and tree fruit orchards could be at risk of attack by ambrosia beetles, especially when freeze stress is preceded by a mild winter. Additional studies are therefore warranted to characterize the freeze stress intolerance of trees commonly planted in ornamental nurseries and tree fruit orchards that are attacked by ambrosia beetles. The incidence of freeze stress and ambrosia beetle attacks on trees within nurseries and orchards should also be characterized and modelled to assist in developing management strategies.

\section{Acknowledgements}

This research was supported by the Floriculture and Nursery Research Initiative (USDA-FNRI), Horticultural Research Institute (HRI) and USDA-ARS National Program 304-Crop Protection and Quarantine (Project 3607-22 000-012-00D). We thank Jenny Barnett (USDA-ARS), Hannah Knapic (USDA-ARS) and Shelby Reutter (USDA-ARS) for technical assistance. We thank the anonymous reviewers for useful comments. Mention of proprietary products or companies does not imply any endorsement or preferential treatment by the USDA-Agricultural Research Service.

\section{References}

Agnello, A., Breth, D., Tee, E., Cox, K. \& Warren, H.R. (2015) Ambrosia beetle - an emergent apple pest. New York Fruit Quarterly, 23, 25-28.

Arora, R. (2018) Mechanism of freeze-thaw injury and recovery: a cool retrospective and warming up to new ideas. Plant Science, 270, 301-313.

Ashworth, E.N. (1992) Formation and spread of ice in plant tissues. Horticultural Reviews, 13, 215-255.

Atkinson, T. (2018) Bark and Ambrosia Beetles [WWW document]. URL http://www.barkbeetles.info/regional_chklist_target_species .php?lookUp=3886) [accessed on 20 September 2018].

Augspurger, C.K. (2009) Spring 2007 warmth and frost: phenology, damage and refoliation in a temperate deciduous forest. Functional Ecology, 23, 1031-1039.

Bartelt, R.J. (1997) Calibration of a commercial solid-phase microextraction device for measuring headspace concentrations of organic volatiles. Analytical Chemistry, 69, 364-372.

Boerner, R.E.J., Runge, S.D., Cho, D.-S. \& Kooser, J.G. (1988) Localized ice storm damage in an Appalachian plateau watershed. American Midland Naturalist, 119, 199-208.

Biedermann, P.H. \& Taborsky, M. (2011) Larval helpers and age polyethism in ambrosia beetles. Proceedings of the National Academy of Sciences, 201107758.

Brand, M.H. (2002) UConn Plant Database [WWW document]. URL http://www.hort.uconn.edu/plants [accessed on 28 May 2013].

Burke, M.J., Gusta, L.V., Quamme, H.A., Weiser, C.J. \& Li, P.H. (1976) Freezing and injury in plants. Annual Review of Plant Physiology, 27, $507-528$. 
CAB International (2018a) Xylosandrus germanus [WWW document]. URL https://www.cabi.org/isc/datasheet/57237 [accessed on 27 August 2018].

CAB International (2018b) Xylosandrus crassiusculus [WWW document]. URL https://www.cabi.org/isc/datasheet/57235 [accessed on 27 August 2018]

Cannell, M.G.R. \& Smith, R.I. (1986) Climatic warming, spring budburst and forest damage on trees. Journal of Applied Ecology, 23, 177-191.

Cappiello, P.E. \& Littlefield, L.E. (1994) Woody landscape plant cold-hardiness ratings. Maine Agricultural and Forest Experiment Station Technical Bulletin, 156, 1-43.

Fall, R. (1999) Biogenic emissions of volatile organic compounds from higher plants. Reactive Hydrocarbons in the Atmosphere (ed. by C. N. Hewitt), pp. 41-96. Elsevier, Inc., New York, New York.

Frank, S.D. \& Ranger, C.M. (2016) Developing a media moisture threshold for nurseries to reduce tree stress and ambrosia beetle attacks. Environmental Entomology, 45, 1040-1048.

French, J.R. \& Roeper, R.A. (1972) Interactions of the ambrosia beetle, Xyleborus dispar (Coleoptera: Scolytidae), with its symbiotic fungus Ambrosiella hartigii (Fungi Imperfecti). The Canadian Entomologist, 104, 1635-1641.

Forney, C.F., Jordan, M.A., Nicholas, K.U.K.G. \& Deell, J.R. (2000) Volatile emissions and chlorophyll fluorescence as indicators of freezing injury in apple fruit. HortScience, 35, 1283-1287.

Fulcher, A., Klingeman, W.E., Chong, J.H. et al. (2012) Stakeholder vision of future direction and strategies for southeastern US nursery pest research and extension programming. Journal of Integrated Pest Management, 3, D1-D8.

Gallego, D., Lencina, J.L., Mas, H., Ceveró, J. \& Faccoli, M. (2017) First record of the granulate ambrosia beetle, Xylosandrus crassiusculus (Coleoptera: Curculionidae, Scolytinae), in the Iberian Peninsula. Zootaxa, 4273, 431-434.

Gara, R.I., Willis, R.L. \& Rhoades, D.F. (1993) Emission of ethanol and monoterpenes by fungal infected lodgepole pine trees. Phytochemistry, 34, 987-990.

Gauss, R. (1960) Ist Xylosandrus germanus Blandf. ein Primärschädling? Anzeiger für Schädlingskunde, 33, 168-172.

Gomez, D.F., Rabaglia, R.J., Fairbanks, K.E.O. \& Hulcr, J. (2018) North American Xyleborini north of Mexico: a review and key to genera and species (Coleoptera, Curculionidae, Scolytinae). ZooKeys, 768, $19-68$.

Gu, L., Hanson, P.J., Post, W.M. et al. (2008) The 2007 eastern US spring freeze: increased cold damage in a warming world? AIBS Bulletin, $\mathbf{5 8}$, $253-262$.

Grégoire, J.-C., Piel, F., De Proft, M. \& Gilbert, M. (2001) Spatial distribution of ambrosia-beetle catches: a possibly useful knowledge to improve mass-trapping. Integrated Pest Management Reviews, 6 , 237-242.

Hänninen, H. (1991) Does climatic warming increase the risk of frost damage in northern trees? Plant, Cell \& Environment, 14, 449-454.

Harrington, T.C., McNew, D., Mayers, C., Fraedrich, S.W. \& Reed, S.E. (2014) Ambrosiella roeperi sp. nov. is the mycangial symbiont of the granulate ambrosia beetle, Xylosandrus crassiusculus. Mycologia, 106, 835-845.

Heidenreich, E. (1960) Primärbefall durch Xylosandrus germanus an Jungeichen. Anzeiger für Schädlingskunde, 33, 5-10.

Henin, J.M. \& Versteirt, V. (2004) Abundance and distribution of Xylosandrus germanus (Blandford 1894) (Coleoptera, Scolytidae) in Belgium: new observations and an attempt to outline its range. Journal of Pest Science, 77, 57-63.

Hufkens, K., Friedl, M.A., Keenan, T.F., Sonnentag, O., Bailey, A., O'keefe, J. \& Richardson, A.D. (2012) Ecological impacts of a widespread frost event following early spring leaf-out. Global Change Biology, 18, 2365-2377.
Hulcr, J. \& Stelinski, L.L. (2017) The ambrosia symbiosis: from evolutionary ecology to practical management. Annual Review of Entomology, 62, 285-303.

Kasson, M.T., O’Donnell, K., Rooney, A.P. et al. (2013) An inordinate fondness for Fusarium: phylogenetic diversity of fusaria cultivated by ambrosia beetles in the genus Euwallacea on avocado and other plant hosts. Fungal Genetics and Biology, 56, 147-157.

Kavčič, A. (2018) First record of the Asian ambrosia beetle, Xylosandrus crassiusculus (Motschulsky) (Coleoptera: Curculionidae, Scolytinae), in Slovenia. Zootaxa, 4483, 191-193.

Kelsey, R.G. (2001) Chemical indicators of stress in trees: their ecological significance and implication for forestry in eastern Oregon and Washington. Northwest Science, 75, 70-76.

Kelsey, R.G. \& Joseph, G. (2001) Attraction of Scolytus unispinosus bark beetles to ethanol in water-stressed Douglas-fir branches. Forest Ecology and Management, 144, 229-238.

Kelsey, R.G., Beh, M.M., Shaw, D.C. \& Manter, D.K. (2013) Ethanol attracts scolytid beetles to Phytophthora ramorum cankers on coast live oak. Journal of Chemical Ecology, 39, 494-506.

Khanizadehi, S., Buszard, D., Fanous, M.A. \& Zarkadas, C.G. (1989) Effect of crop load on seasonal variation in chemical composition and spring frost hardiness of apple flower buds. Canadian Journal of Plant Science, 69, 1277-1284.

Kimmerer, T.W. \& Kozlowski, T.T. (1982) Ethylene, ethane, acetaldehyde, and ethanol production by plants under stress. Plant Physiology, 69, 840-847.

Kimmerer, T.W. \& MacDonald, R.C. (1987) Acetaldehyde and ethanol biosynthesis in leaves of plants. Plant Physiology, 84, 1204-1209.

Kirkendall, L.R. \& Faccoli, M. (2010) Bark beetles and pinhole borers (Curculionidae, Scolytinae, Platypodinae) alien to Europe. Sixty Years of Discovering Scolytine and Platypodine Diversity: A Tribute to Stephen L. Wood, ZooKeys (ed. by A. I. Cognato and M. Knížek), pp. 227-251. Pensoft Publishers, Sofia, Bulgaria.

Kosiba, A.M., Meigs, G.W., Duncan, J.A., Pontius, J.A., Keeton, W.S. \& Tait, E.R. (2018) Spatiotemporal patterns of forest damage and disturbance in the northeastern United States: 2000-2016. Forest Ecology and Management, 430, 94-104.

Kostovcik, M., Bateman, C.C., Kolarik, M., Stelinski, L.L., Jordal, B.H. \& Hulcr, J. (2015) The ambrosia symbiosis is specific in some species and promiscuous in others: evidence from community pyrosequencing. ISME J., 9, 126-138.

Kühnholz, S., Borden, J.H. \& Uzunovic, A. (2001) Secondary ambrosia beetles in apparently healthy trees: adaptations, potential causes and suggested research. Integrated Pest Management Reviews, 6, 209-219.

Landi, L. (2017) Morphological and molecular identification of the invasive Xylosandrus crassiusculus (Coleoptera: Curculionidae: Scolytinae) and its South American range extending into Argentina and Uruguay. Annals of the Entomological Society of America, 110, 344-349.

La Spina, S., De Cannière, C., Dekri, A. \& Grégoire, J.-C. (2013) Frost increases beech susceptibility to Scolytine ambrosia beetles. Agricultural and Forest Entomology, 15, 157-167.

MacDonald, R.C. \& Kimmerer, T.W. (1993) Metabolism of transpired ethanol by eastern cottonwood (Populus deltoides Bartr.). Plant Physiology, 102, 173-179.

Mayers, C.G., McNew, D.L., Harrington, T.C. et al. (2015) Three genera in the Ceratocystidaceae are the respective symbionts of three independent lineages of ambrosia beetles with large, complex mycangia. Fungal Biology, 119, 1075-1092.

Moraal, L.G. \& Hilszczanski, J. (2000) The oak buprestid beetle, Agrilus biguttatus (F.) (Col., Buprestidae), a recent factor in oak decline in Europe. Journal of Pest Science, 73, 134-138.

Motzkin, G., Ciccarello, S.C. \& Foster, D.R. (2002) Frost pockets on a level sand plain: does variation in microclimate help maintain 
persistent vegetation patterns? The Journal of the Torrey Botanical Society, 129, 154-163.

Ningre, F. \& Colin, F. (2007) Frost damage on the terminal shoot as a risk factor of fork incidence on common beech (Fagus sylvatica L.). Annals of Forest Science, 64, 79-86.

NOAA (2012) National Oceanic and Atmospheric Administration, National Climatic Data Center, State of the Climate: National Overview for April 2012 [WWW document]. URL http://www.ncdc .noaa.gov/sotc/national/2012/4 [accessed on 28 May 2013].

Obenland, D.M., Aung, L.H., Bridges, D.L. \& Mackey, B.E. (2003) Volatile emissions of navel oranges as predictors of freeze damage. Journal of Agricultural and Food Chemistry, 51, 3367-3371.

O’Donnell, K., Sink, S., Libeskind-Hadas, R. et al. (2015) Discordant phylogenies suggest repeated host shifts in the Fusarium-Euwallacea ambrosia beetle mutualism. Fungal Genetics and Biology, 82, 277-290.

Oliver, J.B. \& Mannion, C.M. (2001) Ambrosia beetle (Coleoptera: Scolytidae) species attacking chestnut and captured in ethanol-baited traps in middle Tennessee. Environmental Entomology, 30, 909-918.

Ott, E. (2007) Chemical ecology, fungal interactions, and forest stand correlations of the exotic Asian ambrosia beetle Xylosandrus crassiusculus (Coleoptera: Scolytinae). MS Thesis. University rof Louisiana, Baton Rouge, Louisiana.

Rabaglia, R.J., Vandenberg, N.J. \& Acciavatti, R.E. (2009) First records of Anisandrus maiche Stark (Coleoptera: Curculionidae: Scolytinae) from North America. Zootaxa, 2137, 23-28.

Ranger, C.M., Reding, M.E., Schultz, P. \& Oliver, J. (2013) Influence of flood-stress on ambrosia beetle (Coleoptera: Curculionidae, Scolytinae) host-selection and implications for their management in a changing climate. Agricultural and Forest Entomology, 15, 56-64.

Ranger, C.M., Tobin, P.C. \& Reding, M.E. (2015a) Ubiquitous volatile compound facilitates efficient host location by a non-native ambrosia beetle. Biological Invasions, 17, 675-686.

Ranger, C.M., Schultz, P.B., Frank, S.D., Chong, J.H. \& Reding, M.E. (2015b) Non-native ambrosia beetles as opportunistic exploiters of living but weakened trees. PLOS ONE, 10, e0131496.

Ranger, C.M., Reding, M.E., Schultz, P.B. et al. (2016) Biology, ecology, and management of Xylosandrus spp. ambrosia beetles (Coleoptera: Curculionidae: Scolytinae) in ornamental tree nurseries. Journal of Integrated Pest Management, 7, 1-23.

Ranger, C.M., Biedermann, P.H., Phuntumart, V. et al. (2018) Symbiont selection via alcohol benefits fungus farming by ambrosia beetles. Proceedings of the National Academy of Sciences of the United States of America, 115, 4447-4452.

Rassati, D., Lieutier, F. \& Faccoli, M. (2016) Alien wood-boring beetles in Mediterranean regions. Insects and Diseases of Mediterranean
Forest Systems (ed. by T. D. Paine and F. Lieutier), pp. 293-327. Springer, Switzerland.

Reed, S.E., Juzwik, J., English, J.T. \& Ginzel, M.D. (2015) Colonization of artificially stressed black walnut trees by ambrosia beetle, bark beetle, and other weevil species (Coleoptera: Curculionidae) in Indiana and Missouri. Environmental Entomology, 44, 1455-1464.

Reed, S.M. (2005) Japanese snowbell exhibits variability for time of vegetative budbreak and susceptibility to spring freeze damage. HortScience, 40, 542-545.

Romeo, J.T. (2009) New SPME guidelines. Journal of Chemical Ecology, 35, 1383.

SAS Institute (2001) PROC User's Manual, Version 6. SAS Institute, Cary, North Carolina.

Schedl, K.E. (1963) Scolytidae und Platypodidae Afrikans. Band 2. Familie Scolytidae. Revista de Entomologia de Moçambique., 5, $1-594$.

Schoeneweiss, D.F. (1975) Predisposition, stress, and plant disease. Annual Review of Phytopathology, 13, 193-211.

Smith, S.M. \& Hulcr, J. (2015) Scolytus and other economically important bark and ambrosia beetles. Bark Beetles: Biology and Ecology of Native and Invasive Species (ed. by F. E. Vega and R. W. Hofstetter), pp. 495-532. Elsevier Inc., San Diego, California.

Solomon, J.D. (1995) Guide to Insect Borers in North American Broadleaf Trees and Shrubs. Agriculture Handbook (Washington) (AH-706). U.S. Department of Agriculture-Forest Service. Washington, District of Columbia, p. 735.

Timlin, M., Umphlett, N., Shulski, M., Todey, D., Eise, J. \& Anderson, C. (2012) March Heat, April Freezes [WWW document]. URL http:// www.crh.noaa.gov/Image/apx/SpringHeatFreeze.pdf [accessed on 4 November 2013].

Vansteenkiste, D., Tirry, L., Van Acker, J. \& Stevens, M. (2004) Predispositions and symptoms of Agrilus borer attack in declining oak trees. Annals of Forest Science, 61, 815-823.

Vitasse, Y. \& Rebetez, M. (2018) Unprecedented risk of spring frost damage in Switzerland and Germany in 2017. Climatic Change, 149 , 233-246.

Vitasse, Y., Schneider, L., Rixen, C., Christen, D. \& Rebetez, M. (2018) Increase in the risk of exposure of forest and fruit trees to spring frosts at higher elevations in Switzerland over the last four decades. Agricultural and Forest Meteorology, 248, 60-69.

Weber, B.C. \& McPherson, J.E. (1983) World list of host plants of Xylosandrus germanus (Blandford) (Coleoptera: Scolytidae). Coleopterists' Bulletin, 37, 114-134.

Accepted 6 November 2018 